\title{
Morphology
}

\section{The interpretation and significance of morphological abnormalities in jejunal biopsies}

\author{
R. WHITEHEAD
}

From the Department of Pathology, the Gibson Laboratories, Radcliffe Infirmary, Oxford

Despite its limitations conventional microscopic examination of jejunal biopsy material is still one of the most tangible approaches to the investigation of small-intestinal malfunction. The biopsy specimens produced by the various modern flexible instruments are adequate, although small and need careful technical processing if maximum information is to be obtained. Suffice it to say that rapid fixation and the minimum of handling which ensures that sections are cut at right angles to the mucosal surface are essential. The avoidance of tangential cutting artefacts and an examination of several or serial levels throughout the biopsy ensures that truly representative morphology is seen in each specimen.

Stereoscopic examination while the biopsy is in fixative can also be helpful and gives preliminary information which later can be correlated with the histology, but it should never take the place of a proper histological examination. The extra handling and the wiping away of adherent mucus in order to achieve a good dissecting microscopic view should be avoided because of the inevitable distortion, smearing, and crushing artefact which it may cause. Frequently the net result is a loss of much more information than is gained by the stereoscopic study.

In the detection of morphological abnormalities it is mandatory that the observer is acquainted with the normal and, in particular, its variations. The morphology of the small intestine varies along its length, and the normal proximal duodenum not infrequently shows an increased number of stunted and leaf-shaped branching villi when compared with the jejunum. Brunner's glands, traditionally thought to be localized to the duodenum, have a marked variation of distribution often extending to the jejunum, particularly in children (Landboe-Christensen, 1944). Hyperplasia or undue prominence of Brunner's glands is often associated with obvious villous stunting. Biopsies from the proximal duodenum not infrequently show an increased inflammatory cell infiltration with villous atrophy and superficial epithelial degenerative changes which are $\stackrel{\oplus}{\mathcal{E}}$ independent of changes in the remainder of the or duodenum and jejunum. Similar appearances are seen in the immediate vicinity of gastrojejunostomy stomas and are probably more closely related to local factors, including hyperacidity and gastric dysfunction. As the ileum is approached the ratio of goblet cells to absorptive cells increases and the villi tend to become broader and shorter than in the jejunum. The number of lymphoid aggregates increases distally and sometimes proximally they are conspicuous. Villi overlying lymphoid areas are often stubby and may be absent.

Villous architecture is determined in part by the depth of tissue obtained at biopsy. When the muscularis mucosa is present (Fig. 1) the villi are taller, slimmer, and lie more closely together than when this tethering layer is absent. Without a muscularis mucosa and a measure of mucosal stretching due to too much handling of the biopsy the appearance with broad-based, widely-separated villi can be distinctly abnormal (Fig. 2). It is also claimed that villi are shorter on the crests of mucosal folds than in the less exposed valleys between, and that increased trauma in the former site is the cause (Creamer, 1967). This presupposes that such mucosal folds as may be seen at necropsy or surgical specimens are fixed structures and reflect the living state. This is a supposition which cannot be made and which is almost certainly erroneous since the contour of the mucosal surface during life is constantly changing.

It would also appear that villous morphology varies in different ethnic groups. When compared with biopsies from English or north Americans the villi of the Thai (Sprinz, Sribhibhadh, Gangarosa, Benyajata, Kundel, and Halstead, 1962), Africans (Banwell, Hutt, and Tunnicliffe, 1964), and Indians (Baker, Ignatius, Mathan, Vaish, and Chacko, 1962) are shorter, thicker, and have an increased proportion of leaf-shaped forms and short ridges. Whether this is a true racial variation or whether it reflects 


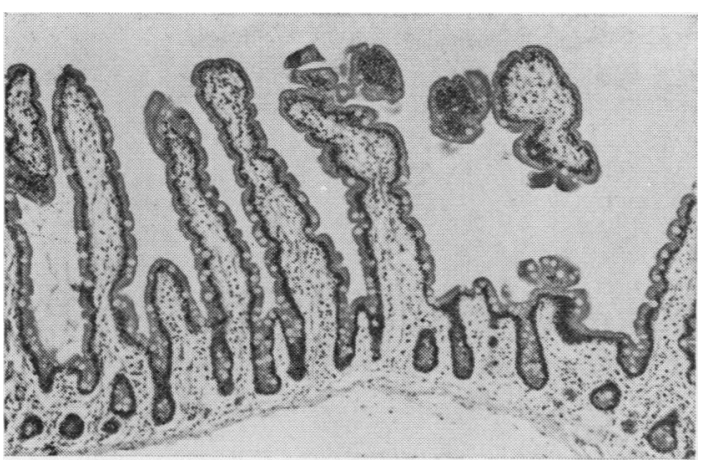

Fig. 1 Jejunal biopsy, normal volunteer $(\times 50)$. Includes muscularis mucosa. Compare with Figures 2, 3,4 , and 5 .

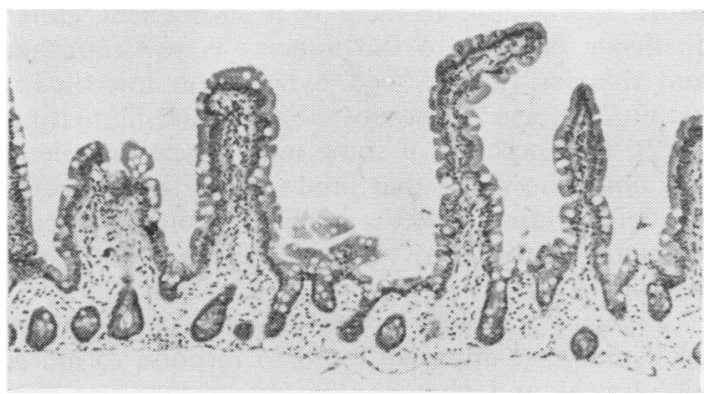

Fig. 2 Jejunal biopsy, normal volunteer $(\times 50)$. Muscularis mucosa is absent. Note the villous spreading and shortening.

altered intraluminal environment because of different standards of health and hygiene has yet to be resolved. There is no doubt that alterations in gut flora in experimental animals have a profound effect on villous shape (Creamer, 1967).

It is obvious that in any investigation involving jejunal morphology, anatomical and pathological variation will be minimized by standardizing the biopsy site. It is now common practice to secure biopsies from a point just distal to the ligament of Treitz under radiological control. Comparisons should be made only with normal as opposed to 'control' groups and these should be selected from the same ethnic and environmental background as the test cases.

Even when all these criteria are fulfilled and there is meticulous care in the technical handling of the material, minor villous abnormalities still cause difficulties in interpretation. It is for this reason that several attempts have been made to replace subjective by more objective quantitative observations (Rubin, Brandborg, Phelps, Taylor, Murray, Steinler, Howry, and Volwiler, 1960; Thurlbeck, Benson, and
Dudley, 1960; Madanagopalan, Shiner, and Rowe, 1965; Stewart, Pollock, Hoffbrand, Mollin, and Booth, 1967; and many others). However, they have been only partially successful because of the lack of proper normal control series and poor selection of abnormal material, eg, Thurlbeck et al (1960) compared tissue obtained at necropsy, at laparotomy, and by tube biopsy, all at unspecified sites. In addition, the methods used are open to criticism: eg, the use of intersecting lines to assess villous surface area (Madanagopalan et al, 1965) without relating this to volume results in gross underestimates if there is any degree of villous separation due to an absent muscularis mucosa or a stretching artefact. Measurements of villous height and depth of glands are only ever approximate since in the majority of biopsies most of the villi are bent over to some degree. The point at which a villus ends and a crypt begins cannot be standardized, and when there is a severe degree of total villous atrophy it becomes impossible. Measurements of epithelial cell height in the normal is feasible, but on the surface epithelium of a flat mucosa of severe gluten-sensitive enteropathy it becomes impossible because of the palisading of cells and the irregularity of basement membranes and brush border.

It is doubtful if these rather insensitive and somewhat inaccurate quantitative methods give any better idea of minor morphological changes than a simple visual assessment by an experienced interpreter, and some workers (Rubin and Dobbins, 1965) have thus resorted to 'the method of blind review'. The complexity of a mathematically accurate method of quantitation of the small intestine is described by Hennig (1956). He shows that in order to obtain accurate information the mucosa must be sectioned and quantitated in three different planes, and the method includes a very large number of observations so that its value for the easy application to human jejunal biopsy tissue is limited. There is thus clearly a need for further investigation into an accurate and reliable quantitative method for the quick comparison of one jejunal biopsy with another.

Morphological abnormalities in jejunal biopsies fall roughly into two categories. The first is so-called villous atrophy which, as will be shown later, is rather unspecific. The second includes all the remaining more specific abnormalities with which villous atrophy may or may not be associated.

\section{Villous Atrophy}

Detailed morphological observations coupled with an increasing knowledge of cell turnover has resulted in the recognition of two types of villous atrophy: 
one associated with hyperplasia of the crypts and one with hypoplasia of the crypts.

CRYPT HYPERPLASTIC VILLOUS ATROPHY

In this type the villi are atrophic or absent but the overall thickness of the mucosa is normal or only slightly decreased, the crypts are hyperplastic and elongated, the crypt cells show an increased number of Paneth cells, and argentaffin cells are often increased. This probably simply reflects that the mucosa is made up wholly of crypts, which are the usual site of these cell types. In its severest form this type of villous atrophy is seen par excellence in gluten-sensitive enteropathy (Fig. 3). It appears to be the direct result of ingestion of gluten in the diet and a toxic action on the mucosa which results in increased cell loss from the villous surface (Croft, Loehry, and Creamer, 1968). Similar appearances are produced by chronic trauma to small-intestinal mucosa in abnormal situations, eg, in jejunum transplanted as an artificial oesophagus (personal observation), in ileostomy stomas, in urinary ileal conduits, or experimentally by the repeated instillation of acid into the jejunum of dogs (Townley, Cass, and Anderson, 1964).

In descriptive accounts of this mucosa the terms 'partial villous atrophy' and 'subtotal villous atrophy' (Doniach and Shiner, 1957) are still in common use and correspond roughly to the dissecting microscopic appearances of convoluted and flat types respectively. In practice, however, there is a continuum of appearances from normal to a completely flat-surfaced mucosa without villous projections. This is paralleled stereoscopically by an increasing number of leaf-shaped villi, short then long ridges, which anastomose, form convolutions, and become progressively lower, sometimes passing through a mosaic phase to end up finally completely flat (Stewart et al, 1967). It is clear that two descriptive terms do not satisfactorily cover the possible histological range. Until a quick and reliable quantitative method is devised a better terminology would therefore be "crypt hyperplasia with total villous atrophy' when there are no villous projections from the surface, and 'mild, moderate or severe partial villous atrophy' when there are.

There is a long list of conditions said to be associated with a jejunal mucosal lesion identical to that in untreated gluten-sensitive enteropathy (childhood and adult coeliac disease), ie, crypt hyperplasia with total or severe partial villous atrophy. Coeliac disease, however, is the only disease state where a causal agent has been identified. Not only is there often a clinical improvement on gluten withdrawal but the jejunal mucosa reverts to normal both morphologically (Pollock, Nagle, Jeejeebhoy, and

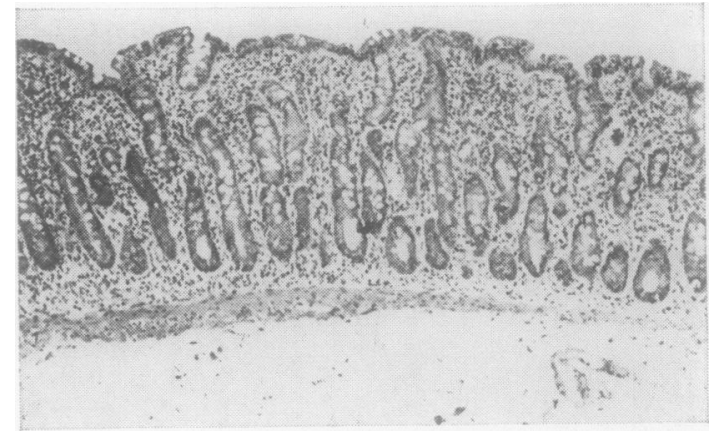

Fig. 3 Jejunal biopsy, gluten-sensitive enteropathy $(\times 50)$. Mucosa shows typical crypt hyperplasia and total villous atrophy.

Coghill, 1970) and histochemically (Riecken, 1970). More specifically, if there is a subsequent gluten challenge damage to the mucosa is re-established and changes can be seen by electron microscopy within 24 hours of the dose (Shiner and Shmerling, 1970). It is perhaps of some importance to note at this point, however, that prednisolone administered to coeliac patients has the same effect on the mucosa as gluten withdrawal (Wall, Douglas, Booth, and Pearse, 1970).

A group of cases otherwise identical to adu coeliac disease apparently fail to respond to gluter withdrawal, and when another disease has also beef. present malabsorption secondary to this has been implied. Failure of a clinical response is not an adequate criterion for assessing gluten sensitivity. A clinical response is difficult to assess, and when it does occur it is widely variable. Failure of a morphological response of the mucosa is a much more objective measurement although this, too, is extremely variable, especially in adults. The longer the disease state has been present the more likely it is that secondary factors or deficiencies may be having an additional effect and it is not surprising that gluten withdrawal results in a much slower recovery of the mucosa. The quality of the glutenfree control is also a factor difficult to assess, especially in adults, and failure to respond is often due to inadvertent or unadmitted gluten ingestion (Pink and Creamer, 1967). Relatively small quan- ô tities of gluten can produce marked mucosal change. Consequently, for a proper diagnosis sequential morphological studies should be performed during a strict period of gluten withdrawal, preferably in a hospitalized patient, and this should be followed by a gluten challenge. Until a better and simpler method is available this should be the minimum requirement for a strict diagnosis of gluten-sensitive enteropathy, and only when it is employed will an assessment of 
primary and secondary non-gluten-sensitive enteropathy be possible. It is pertinent that the malabsorption syndrome so often associated with dermatitis herpetiformis has been shown to be of glutensensitive type (Marks, Whittle, Beard, Robertson, and Gold, 1968). Similarly, those cases of malabsorption in diabetes which have a coeliac-like mucosal lesion are gluten sensitive (Rubin and Dobbins, 1965). The coeliac-like mucosal atrophy seen occasionally in patients with carcinoma outside the bowel (Creamer, 1964) has been shown in some cases to be gluten sensitive (Pollock et al, 1970). In recent years it has become evident that the group of patients with malabsorption syndrome and a jejunal lesion typical of that in coeliac disease who are not gluten-sensitive is certainly very much smaller than earlier papers (eg, Cooke, Fone, Cox, Meynell, and Gaddie, 1963) have suggested. Critical diagnostic tests may, in the future, reduce this number even further, but it seems likely that gluten-sensitive damage over a long period or of a severe degree may reach a state from which recovery is impossible. This would certainly seem to apply to those cases of longstanding gluten-sensitive enteropathy which go on to develop reticulosarcoma (Whitehead, 1968a).

There is an even longer list of conditions associated with minor degrees of crypt hyperplastic villous atrophy (for references see Whitehead, 1968b; Rubin and Dobbins, 1965). Poor histological technique, inexperienced interpretation, and lack of proper controls account for many of the reports and have led to conflicting results and controversy. Only recently, for example, Marks and Shuster (1970) have shown that the mucosal abnormalities described in association with eczema, psoriasis, and rosacea are fictitious. Until evaluated in a much more critical fashion, the presence of jejunal abnormalities associated in the past with cirrhosis of the liver, postgastrectomy states, jejunal diverticulosis, iron-deficiency anaemia, scleroderma, neomycin administration, Crohn's disease not involving the site of jejunal biopsy or neighbouring bowel, ulcerative colitis, chronic pancreatitis, and sarcoidosis must remain the subject of doubt. The validity of the observations of villous abnormalities in various virus infections (Sheehy, Artenstein, and Green, 1964) must also be questioned until reinvestigated in a more critical manner using sequential biopsies during and after recovery from the illness.

In tropical sprue the morphological abnormality varies from 'normal' to 'very abnormal' (Baker and Mathan, 1970), bearing in mind that the 'normal' has to be defined with reference to the local population. With a few exceptions, the most severe lesion

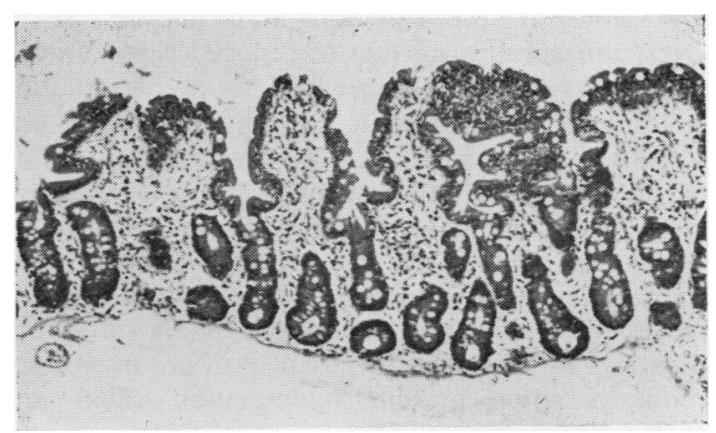

Fig. 4 Jejunal biopsy, tropical sprue $(\times 50)$. Mucosa shows crypt hyperplasia and partial villous atrophy.

is a crypt hyperplastic partial villous atrophy (Fig. 4) and a total villous atrophy is seldom, if ever, seen. The individual histological features in no way differ from those seen in cases of coeliac syndrome with partial villous atrophy. Schenk, Samloff, and Klipstein (1965), however, have claimed that when frozen sections of biopsy tissue in both conditions are stained with oil red $\mathrm{O}$ the appearances in tropical sprue are distinctive. Neutral lipid is said to be found predominantly in the basement membrane in tropical sprue and in the supranuclear cytoplasm in coeliac disease. This is of little value in practice since they were comparing a total villous atrophy of coeliac disease with a partial villous atrophy in tropical sprue, lesions which are distinctive in ordinary preparations. A comparison of cases of both types showing partial villous atrophy is needed.

Sequential biopsy studies after specific treatment with vitamin $\mathbf{B}_{12}$ or folic acid (Swanson, Wheby, and Bayless, 1966) show somewhat variable results, although it is perhaps pertinent that both agents produce maximum effect in the cases with the severest mucosal lesions. Guerra, Wheby, and Bayless (1965) showed marked histological improvement after tetracycline therapy, and over half of their cases had already shown resistance to folic acid and $\mathrm{B}_{12}$ therapy.

\section{CRYPT HYPOPLASTIC VILLOUS ATROPHY}

This lesion has not hitherto received a great deal of attention. It is characterized by shortening of the crypts which show a reduced mitotic rate and a varying degree of villous atrophy. Creamer (1967) was the first to draw attention to it and the lesion has been likened to hypoplastic anaemia in that a decreased cell production rather than an increased loss seems to be involved. It seems, however, that a simple hypoplasia of the crypts may not be the full explanation since experimental reduction of the crypt mitotic rate in man with methotrexate (Trier, 
1962) did not produce villous abnormalities. Moreover, the appearance due to reduced crypt mitotic rate and villous collapse which follows irradiation in animals and in man (Wiernik, Shorter, and Creamer, 1962; Wiernik, 1966) is not identical to crypt hypoplastic villous atrophy. It is, nevertheless, clear that manoeuvres which decrease cell turnover (Creamer, 1967) in the small intestine may greatly influence villous shape and crypt length, and the closest approximation to crypt hypoplastic villous atrophy as it occurs in man is seen in Rhesus monkeys after protein malnutrition (Deo and Ramalingaswami, 1965).

In man, crypt hypoplastic villous atrophy occurs in patients with malignancy (Creamer, 1964), with Paneth cell deficiency (Pink and Creamer, 1967), in hypopituitarism (Riecken, 1970), and in some cases of coeliac disease.

A recent personal observation is that the jejunal mucosa shows a varying degree of crypt hypoplastic villous atrophy in untreated pernicious anaemia (Fig. 5). The crypt and superficial epithelial cells show typical megalocytic changes (Foroozan and Trier, 1967) characterized by large round and pale nuclei (Figs. 6 and 7). The superficial epithelium may otherwise appear relatively normal but in the more severely affected slight nuclear palisading, distortion of the cells, and lack of definition of the brush border in periodic acid Schiff preparations is seen. Mitotic figures are decreased in number and there are fewer Paneth cells which are often poorly granulated. The lamina propria shows a mixed inflammatory infiltrate of varying density with a high lymphocytic preponderance. In one of our cases the infiltrate was extraordinarily heavy and several colonies of bacteria could be identified within the lumen. We have also shown that these changes revert to normal if vitamin $B_{12}$ is given and that in treated pernicious anaemia they are absent. It is tempting to assume that the hypoplastic villous appearance is related to the disturbances of DNA metabolism induced by vitamin $\mathbf{B}_{12}$ deficiency.

Such an explanation might account for some of the cases of crypt hypoplastic villous atrophy seen in malignancy, and it is of interest that in Creamer's case 5 (1964) there was a carcinoma of the stomach although vitamin $\mathbf{B}_{12}$ levels were not measured, and in case 4 , which was associated with carcinoma of the bronchus, there was vitamin $\mathbf{B}_{\mathbf{1 2}}$ deficiency. It is known that vitamin $B_{12}$ deficiency is often present in some cases of coeliac disease. Because vitamin $B_{12}$ is absorbed in the ileum it is not surprising that Stewart et al (1967) have shown a better correlation between abnormality of vitamin $B_{12}$ absorption and the ileal rather than the jejunal mucosal atrophy. Ileal involvement is more common

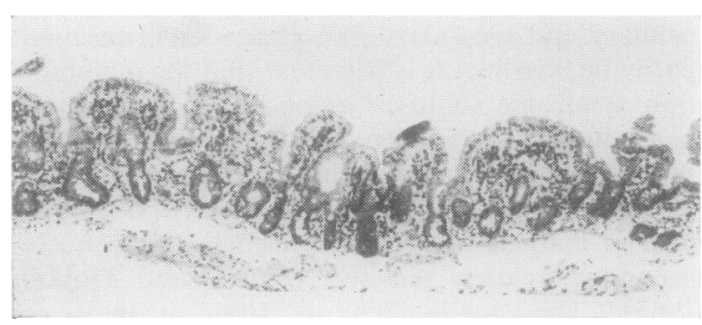

Fig. 5 Jejunal biopsy, untreated pernicious anaemia $(\times 50)$. Mucosa shows crypt hypoplasia and partial villous atrophy.

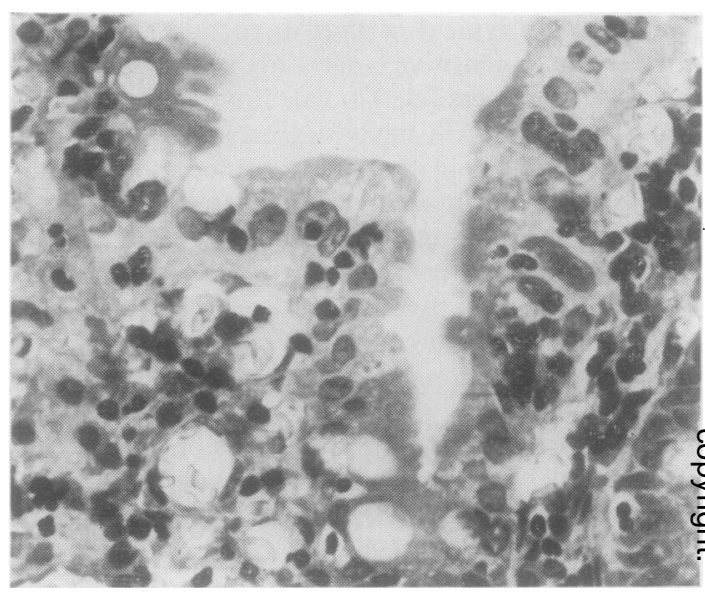

Fig. 6 Jejunal biopsy, untreated pernicious anaemia $(\times 400)$. Surface epithelial cells disorganized, indistinct brush border, and enlarged pale nuclei which are palisaded. Lamina propria contains an increased cellular infiltrate. Compare with Figure 7.

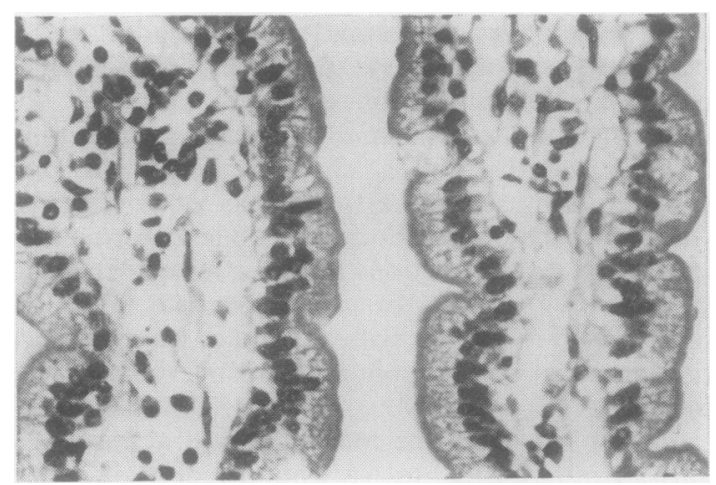

Fig. 7 Jejunal biopsy, normal volunteer $(\times 400)$. Note the surface epithelial cells with distinct brush border and basal nuclei. 
in the severe or longstanding untreated disease and a delayed poor quality response to gluten withdrawal may in part be due to the $B_{12}$ deficiency which is tending to produce crypt hypoplasia. In addition to the superficial absorptive cells crypt cells also mature into Paneth cells and goblet cells. A crypt hypoplasia induced by vitamin $B_{12}$ deficiency might well be expected to lead to Paneth cell deficiency, which has been recorded by Pink and Creamer (1967) in some hypoplastic mucosae associated with malabsorption and a poor response to gluten.

Swanson and Thomassen (1965) describe a tendency towards 'atrophy' of the mucosa in severe tropical sprue. This is associated with a fall in the mitosis count and a decrease in crypt length and number of argentaffin cells. Whatever the agent primarily responsible for the mucosal damage in coeliac disease, tropical sprue, or any other malabsorption syndrome, when the disorder is well established one or more additional factors may begin to influence the morphology of the mucosa.

It seems likely that when accurate quantitation of the jejunal mucosa becomes possible villous atrophy will be shown to occur not only in association with crypt hyperplasia and hypoplasia but also with all stages between. Thus the overall mucosal structure seen at any one stage in disease will depend on the balance between cell loss and cell production. Increased cell proliferation in the crypts and a normal rate of surface loss would be expected to result in villous hypertrophy-a phenomenon already reported in man (Gleeson, Bloom, Polack, Henry, and Dowling, 1970) and well recognized in experimental animals (Dowling, 1967).

\section{Other Morphological Abnormalities}

\section{COELIAC DISEASE WITH PROGRESSIVE}

HY PER PLASIA

Longstanding gluten-sensitive enteropathy may be complicated by bowel or abdominal lymph node sarcoma (Austad, Cornes, Gough, McCarthy, and Read, 1967; Harris, Cooke, Thompson, and Waterhouse, 1967). This has been characterized as a reticulosarcoma by Whitehead (1968a), who also traced its development in the cellular elements of the lamina propria of the bowel wall and the regional lymph nodes through a stage of progressive hyperplasia. The progressive hyperplastic phase is characterized by a deterioration in the clinical picture associated with recurrence of diarrhoea and a reversal of the response to gluten withdrawal, fever, weight loss, abdominal pain, and finger clubbing. In some cases there is a sustained rise in serum IgA levels, which occurs independently of whether there were disturbances in immunoglobulins (Hobbs, Hepner,
Douglas, Crabbé, and Johansson, 1969) before the gluten-free diet was instituted earlier in the disease.

The jejunal biopsy will usually show features which together with the clinical and biochemical abnormalities allow a diagnosis to be made. The commonest finding is a flat mucosa with total villous atrophy and crypt hyperplasia which exhibits an obviously dense cellular infiltrate of the lamina propria (Fig. 8). The mucosa may be slightly thicker than normal, but it is the infiltrate which is of diagnostic importance. Especially in those cases with an increased serum IgA there is a plasma cell component in obvious excess of that seen in an ordinary coeliac mucosa. The plasma cells are in no way cytologically abnormal and they occur in the company of lymphocytes and eosinophils. Eosinophils are always more obvious in the deeper layers of the lamina and may be very conspicuous so that they constitute a striking feature of the histological picture. There will be a variable number of histiocyte-reticulum cells, sometimes found only with difficulty but usually obvious, which show a range of abnormality varying from enlarged normal to frankly atypical and malignant (Fig. 9). It is these cells which subsequently increase in number at the expense of other cell types to produce the reticulum cell sarcoma. At this stage in the disease surface ulceration may occur, not only in the jejunum but also in other areas of the gastrointestinal tract, and the infiltrate often extends below the muscularis mucosa, a feature which may be of value in biopsy material.

A second and less frequent mucosal appearance is also seen in some of these cases (Fig. 10). The infiltrate is essentially the same but somewhat less obvious because the mucosa is of flat crypt-hypoplastic type and there is often a layer of collagen beneath the superficial epithelium. Ulceration may also be a feature here and it is clear in some cases, whilst still at this stage, that healing may occur, but the ulceration is recurrent. Many of the so-called cases of nonspecific ulceration of the small intestine in coeliac disease (Bayless, Kapelowitz, Shelley, Ballinger, and Hendrix, 1967; Jeffries, Steinberg, and Sleisenger, 1968) fall into this category. It is, for example, pertinent that one of the four cases described by Jeffries et al (1968) succumbed shortly after excision of an ulcerated area of bowel to a reticulosarcoma of the bowel and elsewhere. A recent case described in the paper by Barry, Morris, and Read (1970) probably also comes in this category. In this particular patient crypt hypoplastic atrophic mucosa, splenic atrophy, and intestinal ulceration reported as nonspecific in type were associated with a raised serum globulin, but this was not categorized. Sequential jejunal biopsies in all patients with 


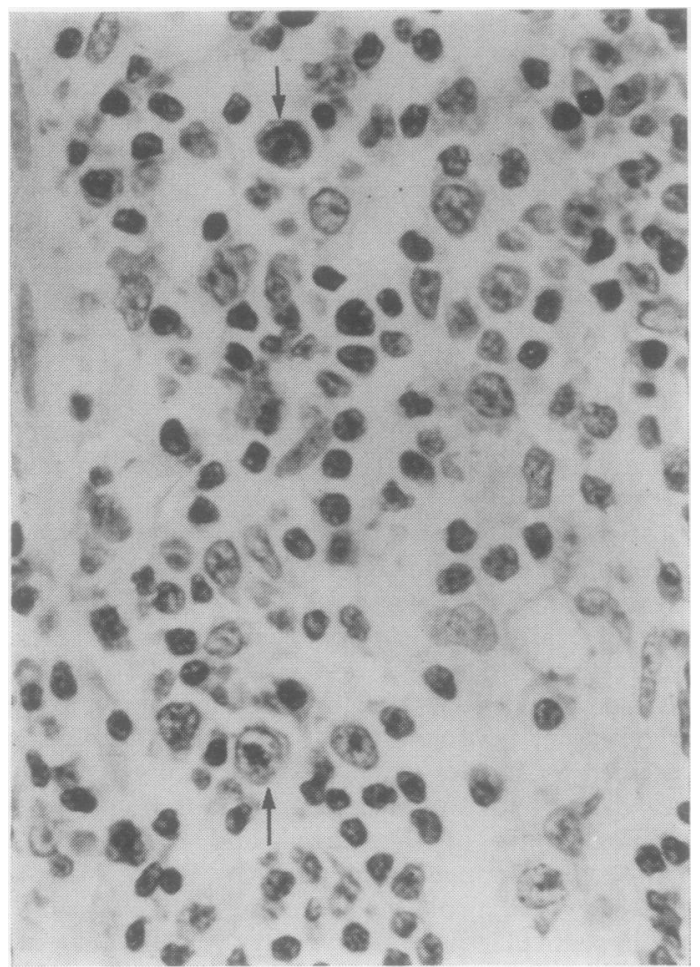

Fig. 9 Detail $(\times 400)$ of cellular infiltrate in Figure 8. Histiocyte-reticulum cells (arrows) are obvious and some are abnormal.

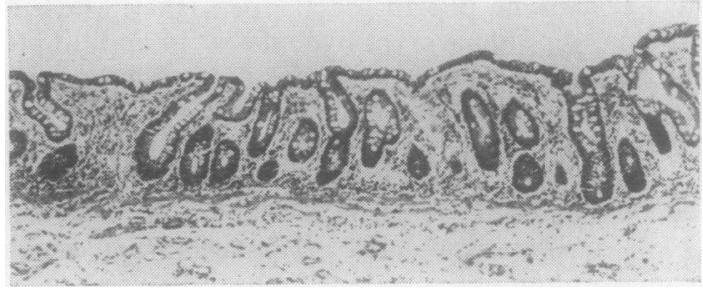

Fig. 10 Jejunal biopsy. longstanding gluten-sensitive enteropathy in stage of 'progressive hyperplasia' $(\times 50)$. Crypts are shortened and villi atrophied with a collagen layer beneath the surface epithelium. The cellular infiltrate is not as marked as in Fig. 8 but note the extension beyond the muscularis mucosa.

coeliac disease or at least in those with a recent change in clinical picture should allow early diag nosis of this condition and subsequently a bettes understanding of it. The time which elapses betwee the stages of progressive hyperplasia and the develop ment of reticulosarcoma seems to vary between a few months to many years - the longest in the cases I have seen is eight years. There is no doubt that many patients die in the phase of progressive hyperplasia from perforation of ulcers or intercurrent infection. This is not infrequently fungal in type and probably reflects a disturbed immunological state as postulated by Hobbs et al (1969). Only when a very careful histological examination of bowel and lymph nodes is made at this stage of the disease by an observer who is aware of the condition will these cases be recognized.

\section{MEDITERRANEAN LYMPHOMA}

Non-Ashkenazi Jews and Israeli Arabs are particularly prone to the development of a primary intestinal and regional node lymphoma which is associated with a malabsorption syndrome (Eidelman, Parkins, and Rubin, 1966). The disease is characterized by the youth of the patients and the more or less diffuse nature of the intestinal lesion. In some patients heavy chains of immunoglobulin IgA are produced in excess (Rambaud, Bognel, Prost, Burnier, le Quintrec, Lambling, Danon, Hurez, and Seligmann, 1968). The condition does not appear to be related to gluten-sensitive enteropathy. Jejunal biopsy reveals a dense cellular infil- 
trate of the lamina propria with a marked plasma cell component, lymphocytes, and abnormal histiocyte-reticulum cells which in some areas dominate the picture. No mention is made of an eosinophil component.

\section{WALDENSTROM'S MACROGLOBULINAEMIA}

Cabrera, de la Pava, and Pickren (1964) report infiltration of the lamina propria by large foamy histiocytes, some of which showed PAS positivity. Similar staining homogeneous material was also seen in the lamina propria and distending the lymphatics in an extracellular situation.

\section{HY POG AMMAGLOBULINAEMIA}

The morphological abnormalities which may occur in the jejunum of patients with hypogammaglobulinaemia is a subject surrounded by confusion. Low levels of gamma globulin and albumin arising secondary to gastrointestinal protein loss might be associated with jejunal changes characteristic of the primary protein-losing enteropathy. Low levels of IgM (Hobbs and Hepner, 1968) and IgA (Crabbé and Heremans, 1967) can occur in gluten-sensitive enteropathy and the jejunum will show only the features of this condition. There seems to be no doubt, however, that diarrhoea and a malabsorption syndrome can complicate hypogammaglobulinaemia of both congenital or acquired type (Barandun, Riva, and Spengler, 1968), but the difficulty in determining the nature of the reported jejunal biopsy abnormalities, if any, is two fold. First, there is considerable difficulty in the classification of the hypogammaglobulinaemias themselves (Good, Peterson, Percy, Finstad, and Cooper, 1968). Secondly, the reported abnormalities of the jejunum have been poorly illustrated and described and usually not clearly related to an easily identified type of gamma globulin deficiency. However, my impression is that, with the exception of one category, ie, nodular lymphoid hyperplasia (Hermans, Huizenga, Hoffman, Brown, and Markowitz, 1966), the jejunum may appear normal, or may show an absence of plasma cells, and if a lymphoid follicle is included it may or may not be atrophic with an absent germinal centre.

Nodular lymphoid hyperplasia is a syndrome characterized by a very low or absent IgA and IgM and a decreased IgG. There is a susceptibility to infections, diarrhoea with or without steatorrhoea, nodular hyperplasia of the lymphoid elements of the small intestine, and giardiasis. The jejunal biopsy and indeed the whole of the small intestine shows a nodular mucosal appearance visible to the naked eye. The nodules vary between 1 and $4 \mathrm{~mm}$ and histologically are composed of normal immature cells and scattered pale histiocytes containing nuclear debris (Figs. 11 and 12). The case illustrated here did not reveal an increased mitotic rate in the follicles although this was reported by Hermans et al (1966). The edge of the germinal centre is characterized by an abrupt edge next to a very thin layer of compressed small lymphocytes (Fig. 12). Beyond the follicles the cellular component of the lamina propria shows a virtual absence of plasma cells, but a very painstaking search may reveal occasional

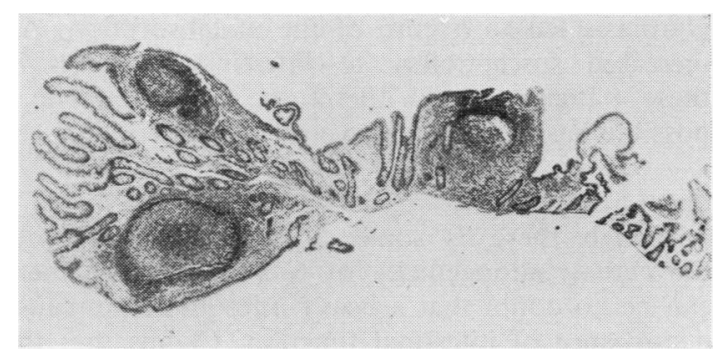

Fig. 11 Jejunal biopsy, nodular lymphoid hyperplasia with hypogammaglobulinaemia $(\times 12)$.

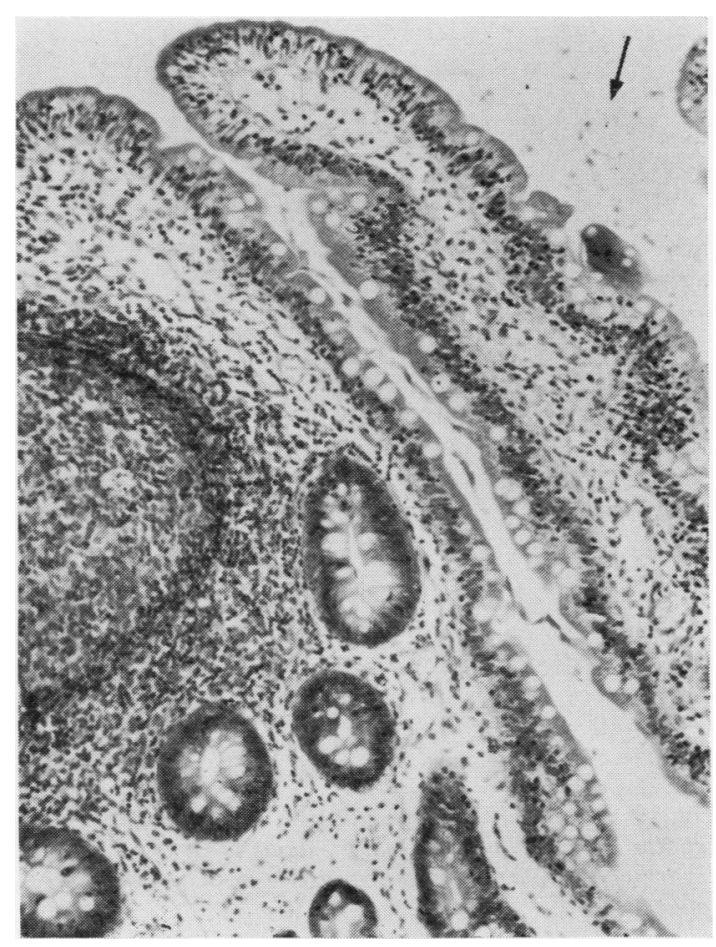

Fig. 12 Detail $(\times 100)$ of Figure 11. Note the germinal centre, its clear-cut margin bounded by small lymphocytes, and giardia (arrow) in the intervillous space. 
examples. Although not mentioned by Hermans et al (1966) in the case described here there was also a patchy and slight increase in eosinophils. The villous pattern is basically normal except over the follicles where the villi are stunted or absent, but the majority of cases show numerous Giardia lamblia (Fig. 12) both in relation to the surface epithelium and in the crypts.

The cause of the disturbance of small-intestinal function in patients with hypogammaglobulinaemia is not fully understood. In the case described above treatment of and subsequent disappearance of the giardiasis led to a cure of the malabsorption. An increased susceptibility to intestinal infection in these patients would therefore seem to form a possible basis for malabsorption.

\section{GIARDIASIS}

Although there is some controversy concerning the actual pathogenicity of Giardia lamblia, there can be no doubt that a heavy infestation can cause disturbance of intestinal function. Claims that the protozoon can invade the surface epithelium (Morecki and Parker, 1967) and the lamina propria (Brandborg, Tankersley, Gottlieb, Barancik, and Sartor, 1967) have not been substantiated by other workers and have never been seen personally in human or in experimental animal material. Even at its most severely involved the jejunal mucosa shows only mild villous atrophy of crypt hyperplastic type with a slight but definite increase in inflammatory cells in the lamina (Figs. 13 and 14). A high proportion of these are often eosinophil polymorphs.

It has been suggested that giardia produces its effect by damage to the mucosa, by nutritional competition between host and parasite, or by a blockade of the mucosa by the parasite (Barbieri, de Brito, Hoshino, Nasciemento, Martins Campos, Quarentei, and Marcondes, 1970). The parasite attaches itself to the villous surface of the absorptive cells via its ventral suction disc and feeds through its dorsal surface. The microvillous layer is the site of most of the digestive enzymes, and this combination of facts makes it entirely feasible that when present in large

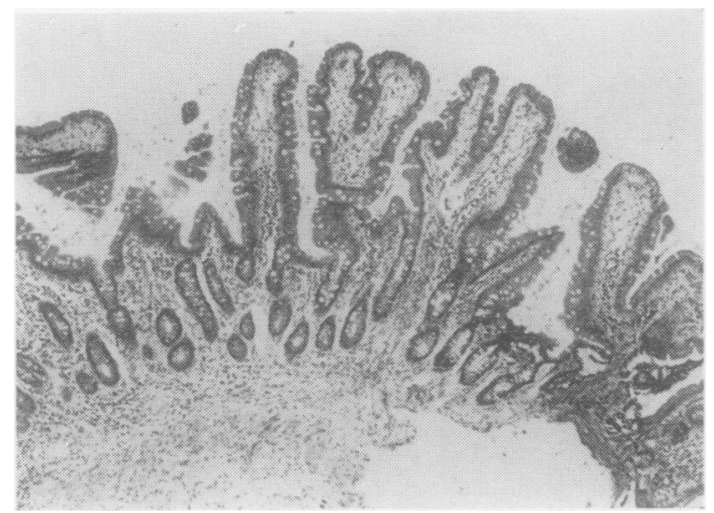

Fig. 13.
Fig. 13 Jejunal biopsy, giardiasis ( $\times 50)$. Note the cellular infiltrate and the minor villous atrophy with crypt hyperplasia. Giardia just visible in the intervillous space.

Fig. 14 Detail $(\times 500)$ of Fig. 13 to show characteristic appearances of giardia in jejunal biopsies.

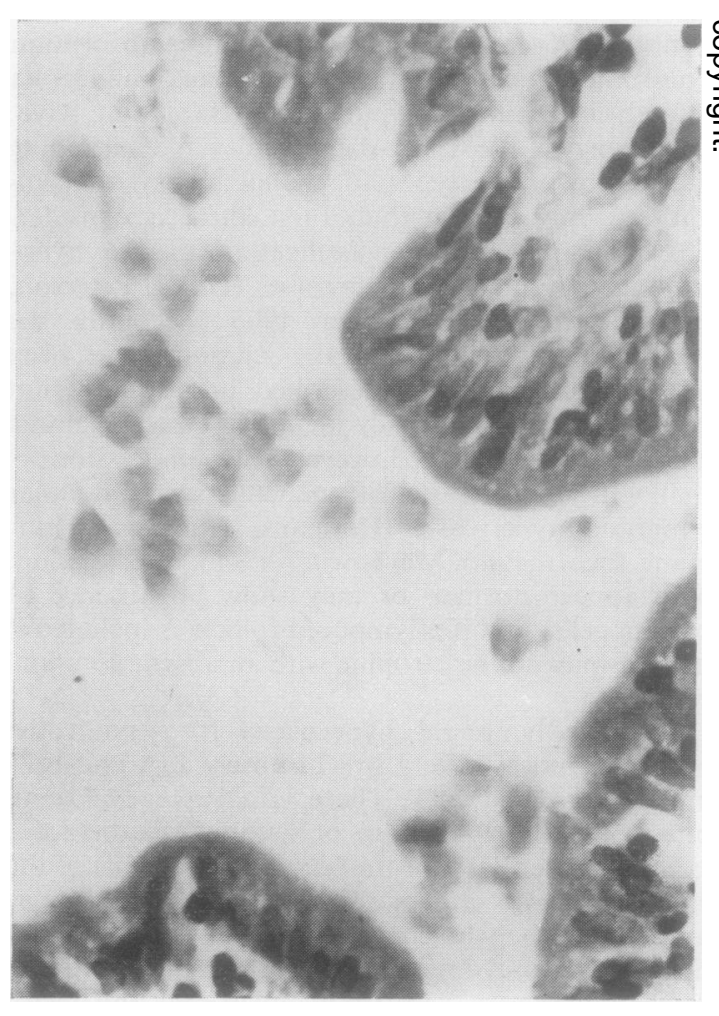

Fig. 14. 
numbers the parasite mechanically interferes with sufficient of the jejunal surface area for there to be disturbance of its function.

\section{HOOKWORM DISEASE}

In this country hookworm disease is no longer the rarity that it was (Miller and Bamforth, 1962; Salem and Truelove, 1964), and in addition to irondeficiency anaemia it is claimed that infestation can also result in a malabsorption syndrome with steatorrhoea (Sheehy, Meroney, Cox, and Soler, 1962). Disturbance of small-intestinal function probably only occurs with an extremely heavy infestation and it is only in this group that morphological abnormalities occur. In personal material these have consisted of crypt hyperplasia and mild to moderate villous atrophy characterized by stunted, branched, and leaf-shaped villi and a few ridges. Occasionally one observes circular spaces in the mucosa (Fig. 15) which represent the channels in which the adult worms lie, and there may be erosions of the superficial epithelium which are presumably the sites where the worms attach themselves to the mucosa via their mouth parts. In the lamina propria, in particular adjacent to the circular channels and erosions, there is often an eosinophil/leucocyte infiltrate.

\section{STRONG YLOIDIASIS}

Diarrhoea and malabsorption syndrome are frequent complications of Strongyloides stercoralis infestation, although it is also often symptomless. Like hookworm disease it is a condition which might be seen with increasing frequency in this country amongst the immigrant population. The incidence in Jamaica based on a small survey was found to be $1 \%$ (Bras, Richards, Irvine, Milner, and Ragbeer, 1964), and Wilson and Thompson (1964) describe a case in a west Indian female immigrant in London. The infestation results invariably in a duodenojejunitis but the whole bowel may be involved in severe cases. A jejunal biopsy may reveal crypt hyperplasia and a varying degree of villous atrophy associated with an inflammatory infiltrate of the lamina propria. Distortion of crypts and erosions of the epithelium can be clearly related to the presence of adult worms, rhabditiform larvae, and ova (Figs. 16a, b, and c). The ova characteristically embed themselves in the crypt walls and within the crypts the larval forms can be seen.

\section{CAPILLARIASIS}

Whalen, Rosenberg, Strickland, Gutman, Cross, Watten, Uylangeo, and Dizou (1969) have recently described a newly discovered infestation of man by a species of the roundworm Capillaria, of epidemic

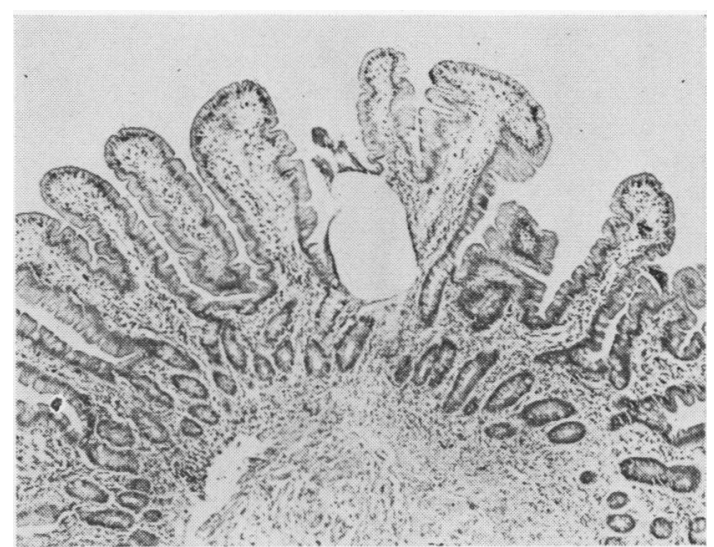

Fig. 15 Jejunal biopsy in heavy hookworm infestation $(\times 50)$. Note the cellular infiltrate, minor villous atrophy and crypt hyperplasia, and the obvious circular channel in the mucosa.

proportions. Occurring in the Philippines the disease takes the form of severe painful diarrhoea associated with protein-losing enteropathy and malabsorption.

Jejunal biopsies are said to show moderate to severe mucosal abnormalities with villous atrophy and inflammatory infiltration of the lamina propria. These changes, however, were no more marked than in controls. In about half the cases examined Capillaria worms were found to have penetrated beneath the superficial mucosa. In postmortem material which has been made available to me from one of the original epidemic cases, eggs were found within the crypts, but in contrast to strongyloidiasis they do not appear to embed themselves in the mucosa (Fig. 17).

ACANTHOCYTOSIS (A $\beta$-LIPOPROTEINAEMIA, BASSEN-KORNZWEIG SYNDROME)

This is a syndrome (Bassen and Kornzweig, 1950) comprising acanthocytosis of red cells, retinitis pigmentosa, central nervous system manifestation, absence of $\beta$-lipoproteins, and steatorrhoea. The jejunal biopsy shows no significant abnormality in villous shape but the superficial epithelium shows typical vacuolation of the apical cytoplasm (Salt, Wolff, Lloyd, Fosbrooke, Cameron, and Hubble, 1960; Lamy, Nezelof, Jos, Frezel, and Rey, 1963). This is seen even in the fasting state and is known to be due to accumulation of lipid. Dobbins (1966) has shown in an electron-microscopic study that the free fatty acids and monoglycerides enter the absorptive cell and are re-esterified in normal fashion. However, Golgi vacuoles do not become distended with lipid nor is there chylomicron formation. This supports the concept that the absorptive 

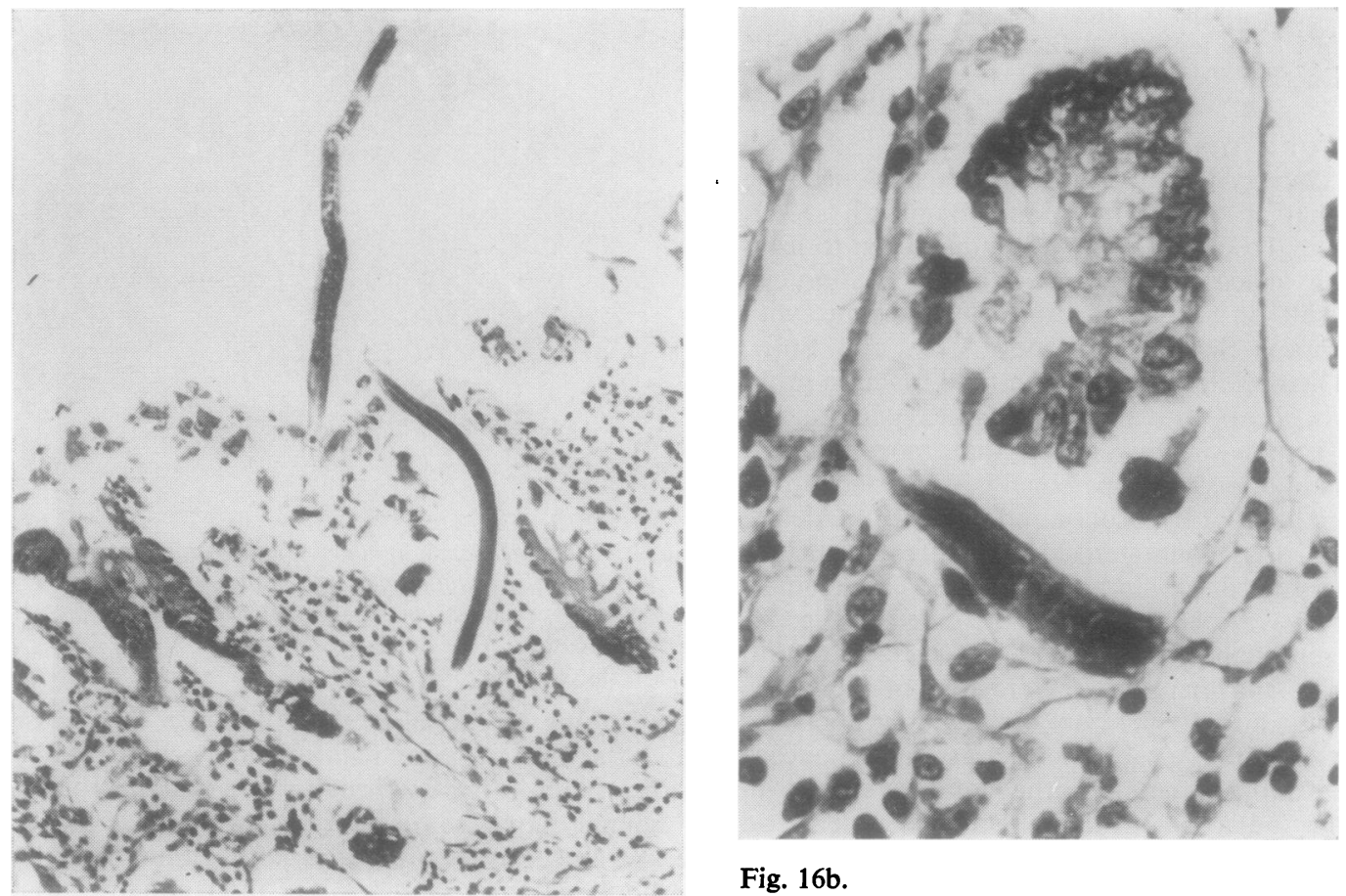

Fig. 16b.

Fig. 16a.

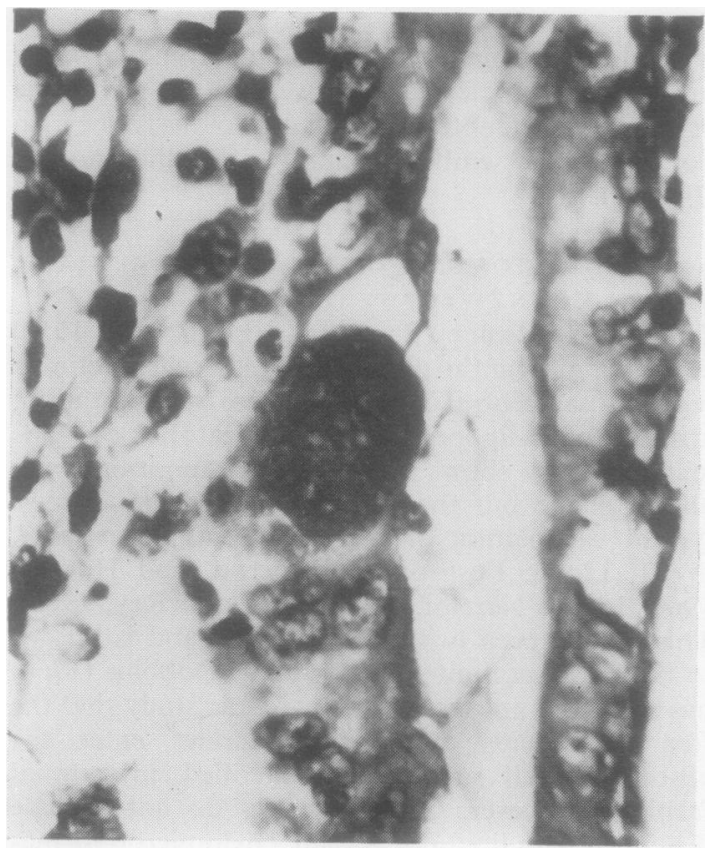

Fig. 16 Strongyloidiasis. 16a Adult worms $(\times 75)$; $16 \mathrm{~b}$ rhabditiform larvae $(\times 500) ; 16 \mathrm{c}$ eggs in jeiunal mucosa $(\times 500)$. (The material for Figs. 16 and 17 was kindly made available by Professor Marcial Rojas, Puerto Rico Medical School.)

Fig. 16c. 


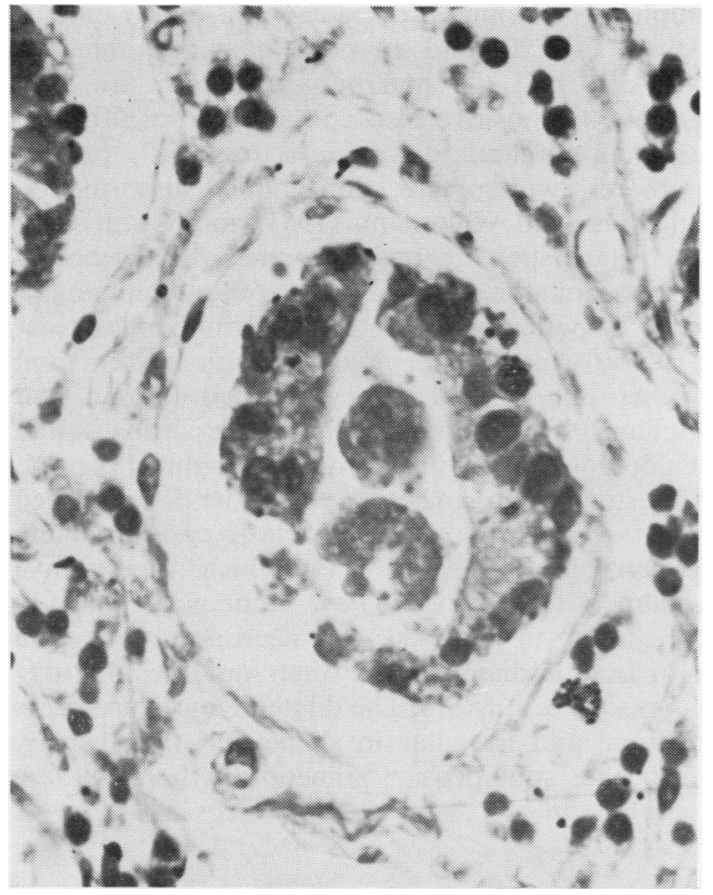

Fig. 17 Capillariasis eggs in jejunal crypt $(\times 500)$. Compare with Figure 16c.

defect is the exit of fat from the absorptive cell due to impaired chylomicron formation with which $\beta$ lipoproteins are concerned (Isselbacher, Scheig, Plotkin, and Caulfield, 1964).

WHIPPLE'S DISEASE

Except for the PAS positivity of the macrophages and recent electron-microscopic observations little has been added to the morphological descriptions

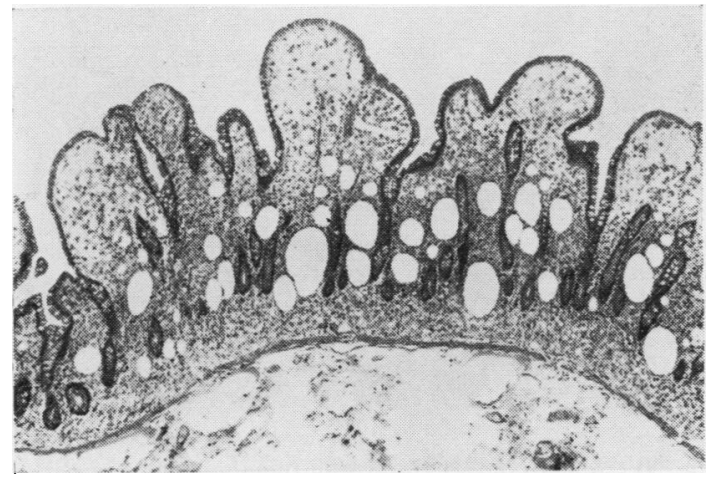

Fig. 18 Jejunal biopsy, Whipple's disease $(\times 50)$. of this condition since it was first described by Whipple (1907) in his original report. The small intestine is always involved and jejural biopsy is the method of choice as a diagnostic procedure (Hendrix and Yardley, 1970). The dissecting microscope reveals several low, bulging, bloated villi of white or yellow appearance. Histologically the villous pattern is distorted by a mucosal infiltrate of large macrophages with a basophilic stippled cytoplasm which surrounds empty spaces (Fig. 18). The macrophages are PAS positive and diastase resistant and this is clearly seen to be due to cytoplasmic inclusions of rods and granules which also occur outside the macrophages lying free in the lamina propria. In preparations stained for iron, macrophages containing haemosiderin are frequently located deep in the lamina propria and the muscularis mucosal cells may contain lipofuscin. Electron-microscopic studies (Watson and Haubrich, 1969) have confirmed Whipple's original suggestion that the basophilic macrophages might contain organisms. The organisms appear as bacilliform bodies which may be seen in the lumen of the bowel in and between the epithelial cells and in and between macrophages in the mucosa and submucosa. In addition to more or less well preserved intracellular forms there are others within lysozomes which show various stages of intracellular digestion. There are also granular and membranous dense bodies which represent the end products of this digestion and which are the counterpart of the PAS-positive granules seen with the light microscope.

Attempts to culture the organisms in Whipple's disease have not, to date, given any consistent results and it is possible that $\mathbf{L}$-forms or mycoplasma are responsible (Charache, Bayless, Shelley, and Hendrix, 1966). Antibiotic therapy is certainly effective in treatment and the disease is no longer inevitably fatal.

The circular spaces in the lamina propria and elsewhere in the other tissues involved contain neutral fat, but exactly how they form is in dispute. Some believe that they are dilated lymphatics, but others deny this, pointing out that the spaces are not lined by endothelium but by macrophages. Endothelium, however, has the capacity to convert into macrophages but lymphatic obstruction has not been demonstrated and there seems to be no good reason why fat should accumulate in dilated lymphatic spaces. Explanation for the lipid deposits is that they are the result of a disturbance in fat absorption, but this hardly explains their presence in sites other than the bowel and mesenteric nodes.

INTESTINAL LYMPHANGIECTASIA

Jejunal biopsy plays an important role in the 
diagnosis of protein-losing enteropathy since many of the 70 or more conditions associated with protein loss from the gastrointestinal tract may be associated with morphological abnormalities. Amongst these are coeliac disease, tropical sprue, hookworm infestation, giardiasis, Crohn's disease, and numerous other inflammatory and neoplastic lesions (for a comprehensive list see Waldmann, 1970). More recently recognized and morphologically distinct is the condition of intestinal lymphangiectasia. This designation should probably be reserved for those cases showing villi with oedematous tips, imparting to the mucosa a pebble-like appearance as seen in the dissecting microscope. Histologically there is oedema of the lamina propria, submucosa, and the surface epithelial cells of the surface epithelium. The latter is said to push the nucleus away from its basal position towards the luminal surface (Mistilis, Skyring, and Stephen, 1965), an appearance however which is also seen in relation to the suction trauma of biopsy. The mucosal lymphatics within the tips of the villi (Fig. 19) are dilated but the villi are only slightly distorted, and there is no villous

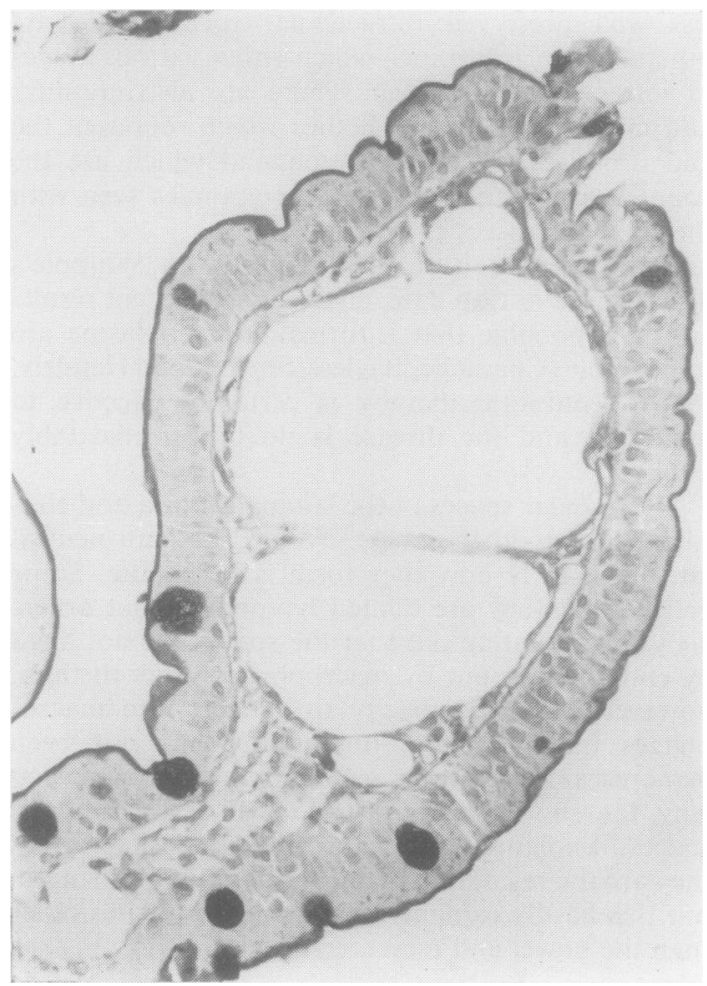

Fig. 19 Jejunal biopsy, intestinal lymphangiectasia $(P A S \times 300)$. Bloated villous tip with dilated lymphatics. atrophy. The lamina propria contains foamy macrophages (Fig. 20) and an occasional multinucleate giant cell, and the macrophages which are only weakly PAS positive also contain neutral fat. The intestinal lymphatic dilatation is frequently part of a more widespread congenital abnormality. Pomerantz and Waldmann (1963) and Mistilis et al (1965) have shown ectasia of some and absence of other lymphatics in lower extremity lymphangiograms in patients with intestinal lymphangiectasia. It is also claimed that any lymphatic obstruction, whether due to malignancy, fibrosis (Rubin and Dobbins, 1965), or simply to congestive cardiac failure (Waldmann, 1970) may produce a similar picture. Intestinal lymphangiectasia must be distinguished from the entity of lymphangiectatic cysts (Shilken, of Zerman, and Blackwell, 1968), which usually have no clinical significance. These occur particularly in the jejunum in some $20 \%$ of necropsies. They are up to $1 \mathrm{~cm}$ in diameter and often multiple, and may be biopsied during life. The dilated lymphatic spaces are large and irregular in shape and they usually affect the submucosa. Sometimes the villi are

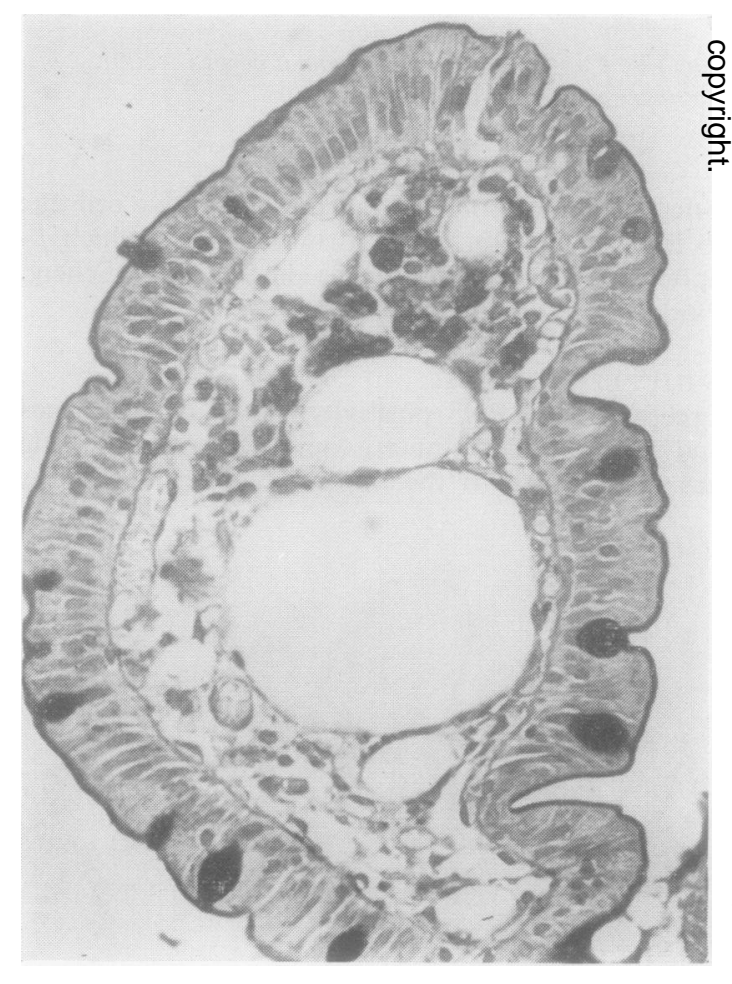

Fig. 20 Jejunal biopsy, intestinal lymphangiectasia $(P A S \times 300)$. Macrophages around lymphatic spaces. 
involved but, in contrast to lymphangiectasia, several adjacent villi appear distorted by large and irregular lymphatic spaces whilst their neighbours are entirely normal (Fig. 21). There may be lipidcontaining histiocytes and these are found not in the lamina propria but within the lymphatic spaces. The spaces frequently contain pink inspissated lymph rich in neutral fat. A further contrast with diffuse intestinal lymphangiectasia is that lipofuscinosis is not seen.

A further condition recently recognized is allergic gastroenteropathy (Waldmann, Wochner, Laster, and Gordon, 1967), a protein-losing enteropathy occurring in children who also show anaemia, eosinophilia, and growth retardation. The jejunum also shows a normal villous architecture but there is an eosinophilic infiltration in the lamina propria. Sometimes there is associated asthma, eczema and rhinitis, and an allergy to ingested milk protein seems to be the cause.

In any cause of hypoalbuminaemia the muscularis mucosa and occasional histiocytes in the lamina propria and submucosa of the jejunal biopsy may show lipofuscin pigmentation (Fig. 22). It is probably only found in these sites when pigmentation of

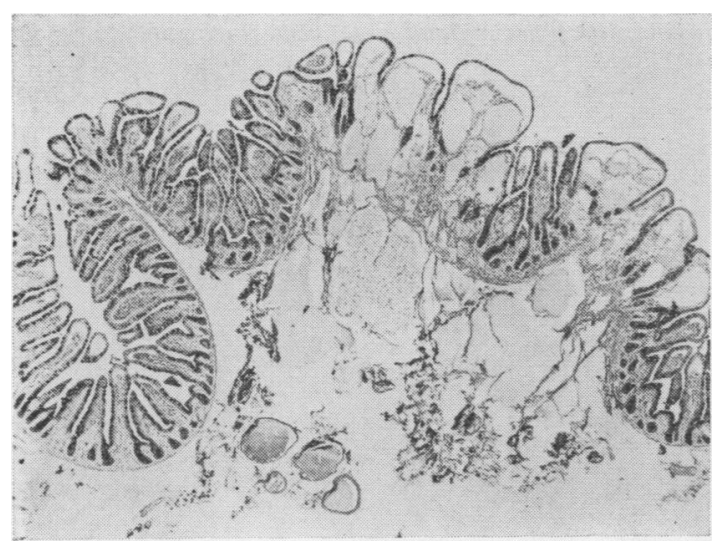

Fig. 21.

Fig. 21 Lymphangiectatic cyst in jejunum $(P A S \times 10)$. Large, irregular lymphatic spaces distort the villous pattern and contain coagulated lymph and macrophages. Note that the villi adjacent to the lesion are normal.

Fig. 22 Jejunal biopsy, hypoalbumenaemia in coelic disease with protein-losing enteropathy $(\times 250)$. Muscularis mucosal cells (arrows) contain lipofuscin pigment. other smooth muscle is fairly heavy. The pigment is PAS positive, autofluorescent in ultraviolet light, can be stained by sudan black, and is usually acidfast with Ziehl-Neelsen's stain. The significance of the pigmentation is not fully understood, but it is thought to be related to vitamin $E$ deficiency (Ansanelli and Lane, 1957; Tofler, Hukill, and Spiro, 1963; Binder, Herting, Hurst, Finch, and Spiro, 1965), and to hypoalbuminaemia (Richards, 1959). In human jejunal biopsy material, when lipofuscin pigmentation is seen hypoalbuminaemia is always present. There is a close inter-relationship between vitamin $E$ and protein metabolism (Fox, 1967), and deficiency of a potent antioxidant such as vitamin $E$ could certainly contribute to the production of lipofuscin pigment which is seen in a variety of body tissues as a concomitant of aging. It is thought to be the result of a progressive oxidation of cellular constituents.

DISACCHARIDASE DEFICIENCIES

There is some disagreement concerning the morphological changes in jejunal biopsies in both primary and acquired disaccharidase deficiencies. In a carefully controlled study which included normal

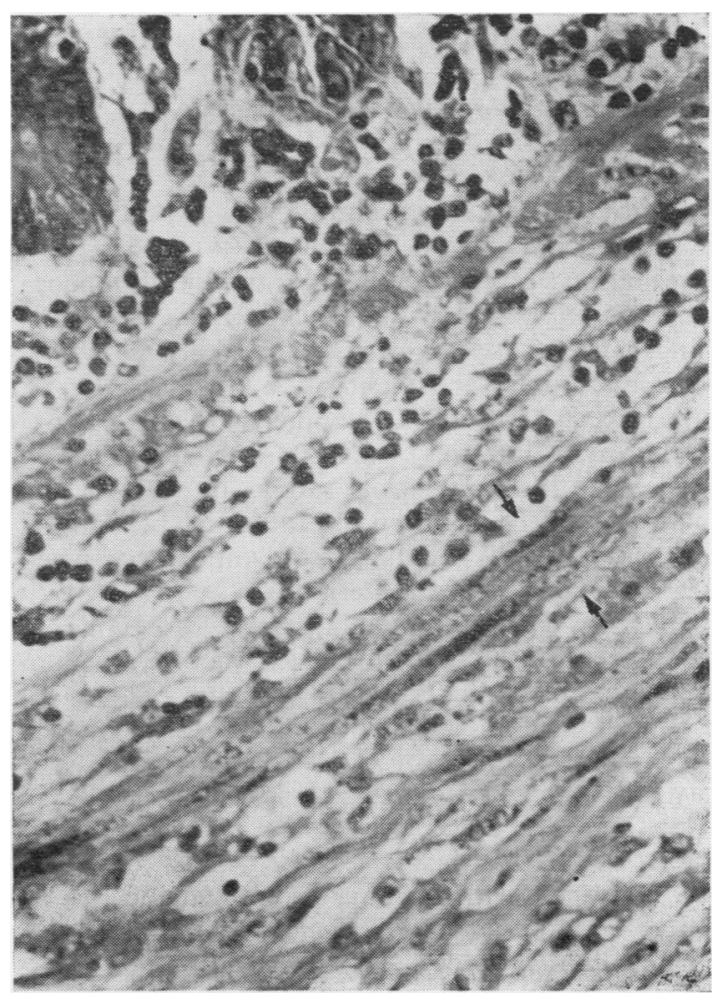

Fig. 22. 
control volunteers, A. S. Peña and R. Whitehead (in preparation) have examined the relationship of disaccharidase levels and morphological appearances in jejunal biopsies from large groups of patients with (1) miscellaneous diseases not directly related to the gastrointestinal tract; (2) Crohn's disease; (3) ulcerative colitis; (4) pernicious anaemia; (5) irondeficiency anaemia; (6) giardiasis; (7) glutensensitive enteropathy; and smaller numbers of cases with tropical sprue, hypogammaglobulinaemia, hookworm disease, and diarrhoea of other causes. This work is to be published in full but several important points have emerged. In isolated lactase deficiency no detectable abnormality of the jejunal mucosa can be demonstrated in the light microscope or by conventional electron microscopy. Where there are morphological abnormalities in the jejunal biopsies all the disaccharidases measured, ie, lactase, maltose, and sucrose, are depressed compared with the normal. Preliminary results estimating villous surface area by relating it to volume indicate that depression of disaccharidase levels is a sensitive index of decrease in villous surface area, ie, villous atrophy. For example, the depression of enzymes in the jejunal mucosa in pernicious anaemia is much less than in untreated coeliac disease and in the latter during treatment the enzyme level corresponds closely with the degree of villous atrophy.

\section{Miscellaneous Morphological Findings}

\section{METAPLASIA}

The intestinal crypts may on occasion be replaced by simple mucous glands of pyloric type (Fig. 23). These always occur above the muscularis mucosa and thus are easily distinguishable from Brunner's glands. The change is often referred to as pyloric gland metaplasia and is simply a manifestation of the marked metaplastic potential of the epithelium of the gastrointestinal tract as a whole. In my experience this metaplasia rarely, if ever, occurs unless there is or has been ulceration in the vicinity, and this is clearly of diagnostic importance when seen in jejunal biopsy material.

The superficial epithelium may also undergo metaplasia to a superficial gastric type of epithelium (Fig. 24). This is seen in the duodenum or jejunum in conditions of high gastric acid secretion (James, 1964; Rhodes, 1964), but like pyloric metaplasia it may also appear near areas of ulceration.

\section{HAEMOSIDERIN PIGMENTATION}

Not infrequently the lamina propria in the tips of villi will contain groups of macrophages filled with haemosiderin granules. This occurs in the normal but is much more frequent after oral or parenteral iron administration. In transfusional haemosiderosis the appearances are accentuated and sometimes pigmented macrophages appear to be traversing the epithelium. The epithelial cells themselves do not contain iron which is in contrast to the appearances in haemochromatosis (Astaldi, Meardi, and Lisino, 1966). In addition to the epithelial haemosiderin

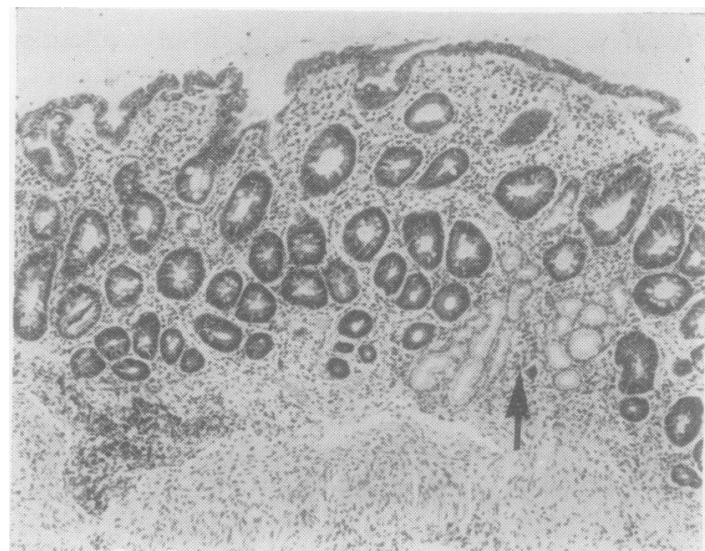

Fig. 23 Jejunal biopsy, crypt hyperplasia, and villous atrophy with pyloric gland metaplasia (arrow) $(\times 250)$.

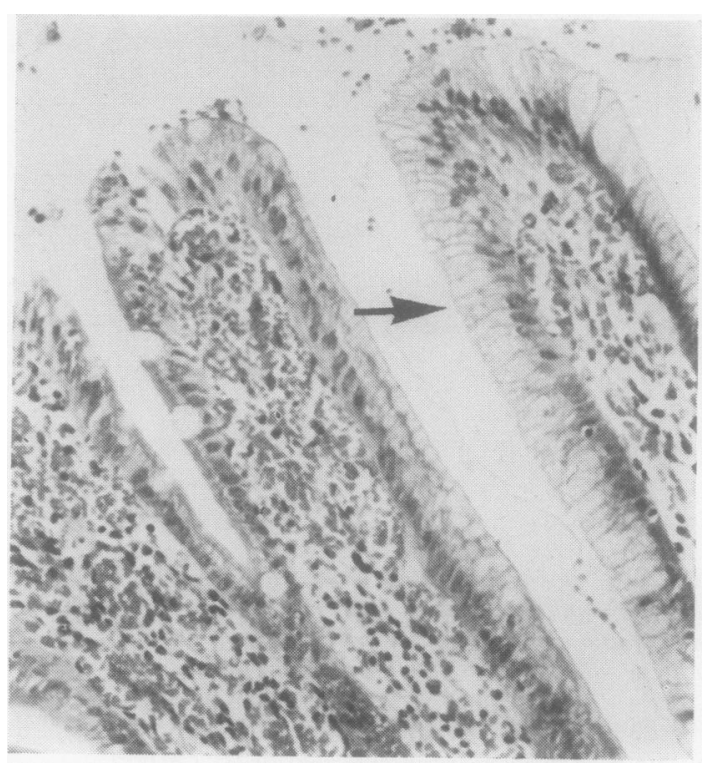

Fig. 24 Jejunal biopsy, region of Crohn's ulceration $(\times 250)$. Absorptive epithelium shows gastric superficial epithelial metaplasia (arrow). 
the pattern of distribution of the pigment macrophages is also different. In haemochromatosis they tend to be more diffusely scattered throughout the lamina propria and around vessels-a distribution similar to that seen in Whipple's disease.

\section{References}

Ansanelli, V., Jr., and Lane, N. (1957). Lipochrome (ceroid) pigmentation of the small intestine. Ann. Surg., 146, 117-123.

Astaldi, G., Meardi, G., and Lisino, T. (1966). The iron content of jejunal mucosa obtained by Crosby's biopsy in haemochromatosis and haemosiderosis. Blood, 28, 70-82.

Austad, W. I., Cornes, J. S., Gough, K. R., McCarthy, C. F., and Read, A. E. (1967). Steatorrhoea and malignant lymphoma. Amer. J. dig. Dis., 12, 475-490.

Baker, S. J., Ignatius, M., Mathan, V. I., Vaish, S. K., and Chacko, C. C. (1962). Intestinal Biopsy, p. 184, edited by G. E. Wolstenholme and M. P. Cameron. (Study group No. 14.) Ciba Foundation, London.

Baker, S. J., and Mathan, V. I. (1970). In Modern Trends in Gastroenterology, vol. 4, p. 198, edited by W. I. Card and B. Creamer. Butterworth, London.

Banwell, J. G., Hutt, M. S. R., and Tunnicliffe, R. (1964). Observations on jejunal biopsy in Ugandan Africans. E. Afr. med. J., 41, 46-54.

Barandun, D., Riva, G., and Spengler, G. A. (1968). Immunological deficiency diseases in man. Birth Defects: Original Article Series IV, 1, p. 40 , edited by D. Bergsma and R. A. Good. The National Foundation-March of Dimes, New York.

Barbieri, D., Brito, T. de, Hoshino, S., Nasciemento, O. B., Martins Campos, J. V., Quarentei, G., and Marcondes, E. (1970). Giardiasis in childhood. Absorption tests and biochemistry, histochemistry, light, and electron microscopy of jejunal mucosa. Arch. Dis. Childh., 45, 466-472.

Barry, R. E., Morris, J. S., and Read, A. E. A. (1970). A case of small intestinal mucosal atrophy. Gut, 11, 743-747.

Bassen, F. A., and Kornzweig, A. L. (1950). Malformation of the erythrocytes in a case of atypical retinitis pigmentosa. Blood, 5, 381-387.

Bayless, T. M., Kapelowitz, R. F., Shelley, W. M., Ballinger, W. F., and Hendrix, T. R. (1967). Intestinal ulceration-a complication of coeliac disease. New Engl. J. Med., 276, 996-1002.

Binder, H. J., Herting, D. C., Hurst, V., Finch, S. C., and Spiro, H. M. (1965). Tocopherol deficiency in man. New Engl. J. Med., 273, 1289-1297.

Brandborg, L. L., Tankersley, C. B., Gottlieb, S., Barancik, M., and Sartor, V. E. (1967). Histological demonstration of mucosal invasion by Giardia lamblia in man. Gastroenterology, 52, 143-150.

Bras, G., Richards, R. C., Irvine, R. A., Milner, P. F. A., and Ragbeer, M. M. S. (1964). Infection with Strongyloides stercoralis in Jamaica. Lancet, 2, 1257-1260.

Cabrera, A., de la Pava, S., and Pickren, J. W. (1964). Intestinal localisation of Waldenstrom's disease. Arch. intern Med., 114, 399-407.

Charache, P., Bayless, T. M., Shelley, W. M., and Hendrix, T. R. (1966). Atypical bacteria in Whipple's disease. Trans. Ass. Amer. Phycns, 79, 399-408.

Cooke, W. T., Fone, D. J., Cox, E. V., Meynell, M. J., and Gaddie, R. (1963). Adult coeliac disease. Gut, 4, 279-291.

Crabbé, P. A., and Heremans, J. F. (1967). Selective IgA deficiency with steatorrhoea. Amer. J. Med., 42, 319-326.

Creamer, B. (1964). Malignancy and the small intestinal mucosa. Brit. med. J., 2, 1435-1436.

Creamer, B. (1967). The turnover of the epithelium of the small intestine, Brit. med. Bull., 23, 226-230.

Croft, D. N., Loehry, C. A., and Creamer, B. (1968). Small bowel cell loss and weight loss in the coeliac syndrome. Lancet, 2, 68-70.

Deo, M. G., and Ramalingaswami, V. (1965). Reaction of the small intestine to induced protein malnutrition in Rhesus monkeysa study of cell population kinetics in the jejunum. Gastroenterology, 49, 150-157.

Dobbins, W. O. (1966). An ultrastructural study of the intestinal mucosa in congenital $\beta$-lipoprotein deficiency with particular emphasis upon the intestinal absorptive cell. Gastroenterology, 50, 195-210.
Doniach, D., and Shiner, M. (1957). Duodenal and jejunal biopsies. Gastroenterology, 33, 71-86.

Dowling, R. H. (1967). Compensatory changes in intestinal absorption. Brit. med. Bull., 23, 275-278.

Eidelman, S., Parkins, R. A., and Rubin, C. E. (1966). Abdominal lymphoma presenting as malabsorption. Medicine (Baltimore), 45, 111-137.

Foroozan, P., and Trier, J. S. (1967). Mucosa of the small intestine in pernicious anaemia. New Engl. J. Med., 277, 553-559.

Fox, B. (1967). Lipofuscinosis of the gastrointestinal tract in man. J. clin. Path., 20, 806-813.

Gleeson, M. H., Bloom, S. R., Polak, J. M., Henry, K., and Dowling, R. H. (1970). An endocrine tumour in kidney affecting small bowel structure, motility, and function. (Abstr.) Gut, 11, 1066.

Good, R. A., Peterson, R. D. A., Percy, D. Y., Finstad, J., and Cooper, M. D. (1968). Immunological deficiency diseases in man. Birth Defects: Original Article Series, IV, 1, p. 17, edited by D. Bergsma and R. A. Good. The National FoundationMarch of Dimes, New York.

Guerra, R., Wheby, M. S., and Bayless, T. M. (1965). Long-term antibiotic therapy in tropical sprue. Ann. intern. Med., 63, 619-634.

Harris, O. D., Cooke, W. T., Thompson, M., and Waterhouse, J. A. H. (1967). Malignancy in adult coeliac disease and idiopathic steatorrhoea. Amer. J. Med., 42, 899-912.

Hendrix, T. R., and Yardley, J. H. (1970). Modern Trends in Gastroenterology, vol. 4, p. 229, edited by W. I. Card and B. Creamer. Butterworth, London.

Hennig, A. (1956). Inhalt einer aus Papilleu oder Zotten gebildeten Fläche. Mikroscopie, 11, 206-213.

Hermans, P. E., Huizenga, K. A., Hoffman, H. N., Brown, A. L., and Markowitz, H. (1966). Dysgammaglobulinaemia associated with nodular lymphoid hyperplasia of the small intestine. Amer. J. Med., 40, 78-79.

Hobbs, J. R., and Hepner, G. W. (1968). Deficiency of $\gamma$ M-globulin in coeliac disease. Lancet, 1, 217-220.

Hobbs, J. R., Hepner, G. W., Douglas, A. P., Crabbé, P. A., and Johansson, S. G. O. (1969). Immunological mystery of coeliac disease. Lancet, 2, 649-650.

Isselbacher, K. J., Scheig, R., Plotkin, G. R., and Caulfield, J. B. (1964). Congenital $\beta$-lipoprotein deficiency; a hereditary disorder involving a defect in the absorption and transport of lipids. Medicine (Baltimore), 43, 347-361.

James, A. H. (1964). Gastric epithelium in the duodenum. Gut, 5, 285-294.

Jeffries, G. H., Steinberg, H., and Sleisenger, M. H. (1968). Chronic ulcerative (nongranulomatous) jejunitis. Amer. J. Med., 44, 47-59.

Lamy, M., Nezelof, C., Jos, J., Frezel, J., and Rey, J. (1963). La biopsie de la muqueuse intestinale chez l'enfant. Premiers résultats d'une étude des syndromes de malabsorption. Presse méd., 71, 1267-1270.

Landboe-Christensen, E. (1944). The duodenal glands of Brunner in man, their distribution and quantity. Acta path. microbiol. scand., Suppl. 52, 240.

Madanagopolan, N., Shiner, M., and Rowe, B. (1965). Measurements of small intestinal mucosa obtained by peroral biopsy. Amer. J. Med., 38, 42-53.

Marks, J., and Shuster, S. (1970). Small intestinal mucosal abnormalities in various skin diseases-fact or fancy? Gut, 11, 281-291.

Marks, R., Whittle, M. W., Beard, R. J., Robertson, W. B., and Gold, S. C. (1968). Small bowel abnormalities in dermatitis herpetiformis. Brit. med. J., 1, 552-555.

Miller, G. A. H., and Bamforth, J. (1962). Ancylostomiasis in England. Brit. med. J., 1, 1661-1662.

Mistilis, S. P., Skyring, A. P., and Stephen, D. D. (1965). Intestinal lymphangiectasia. Mechanism of enteric loss of plasma protein and fat. Lancet, 1, 77-79.

Morecki, R., and Parker, J. G. (1967). Ultrastructural studies of the human Giardia lamblia and subadjacent jejunal mucosa in a subject with steatorrhoea. Gastroenterology, 52, 151-164.

Pink, I. J., and Creamer, B. (1967). Response to a gluten free diet of patients with coeliac syndrome. Lancet, 1, 300.304.

Pollock, D. J., Nagle, K. E., Jeejeebhoy, K. N., and Coghill, N. F. (1970). The effect on jejunal mucosa of withdrawing and adding dietary gluten in cases of idiopathic steatorrhoea. Gut, 11, 567-575.

Pomerantz, M., and Waldmann, T. (1963). Systemic lymphatic abnormalities associated with gastrointestinal protein loss 
secondary to intestinal lymphangectasia. Gastroenterology, 45, 703-711.

Rambaud, J. C. , Bognel, C., Prost, A., Burnier, J. J., Quintrec, Y. Le., Lambling, A., Danon, F., Hurez, D., and Seligmann, M. (1968). Clinico-pathological study of a patient with 'Mediterranean' type of abdominal lymphoma and a new type of IgA abnormality ('Alpha Chain Disease'). Digestion, 1, 321-336.

Reicken, E. O. (1970). In Modern Trends in Gastroenterology, vol. 4 , p. 20 , edited by W. I. Card and B. Creamer. Butterworth, London.

Rhodes, J. (1964). Experimental production of gastric epithelium in the duodenum. Gut, 5, 454-458.

Richards, W. C. D. (1959). Pigmentation of gastro-intestinal muscle. Lancet, 1, 683.

Rubin, C. E., Brandborg, L. L., Phelps, P. D., Taylor, H. C., Murray, C. V., Steinler, R., Howry, C., and Volwiler, W. (1960). Studies of coeliac disease. II Gastroenterology, 38, 517-535.

Rubin, C. E., and Dobbins, W. O. (1965). Peroral biopsy of the small intestine. Gastroenterology, 49, 676-697.

Salem, S. N., and Truelove, S. C. (1964). Hookworm disease in immigrants. Brit. med. J., 1, 1074-1077.

Salt, H. B., Wolff, O. H., Lloyd, J. K., Fosbrooke, A. S., Cameron, A. H., and Hubble, D. V. (1960). On having no beta-lipoprotein. A syndrome comprising a-beta-lipoproteinaemia, acanthocytosis and steatorrhoea. Lancet, 2, 325-329.

Schenk, E. A., Samloff, I. M., and Klipstein, F. A. (1965). Morphologic characteristics of jejunal biopsy in coeliac disease and tropical sprue. Amer. J. Path., 47, 765-781.

Sheehy, T. W., Artenstein, M. S., and Green, R. W. (1964). Small intestinal mucosa in certain viral diseases. J. Amer. med. Ass., 190, 1023-1028

Sheehy, T. W., Meroney, W. H., Cox, R. S., and Soler, J. E. (1962). Hookworm disease and malabsorption. Gastroenterology, 42 148-156.

Shilken, K. B., Zerman, B. J., and Blackwell, J. B. (1968). Lymphangiectatic cysts of the small bowel. J. Path. Bact., 96, 353-358.

Shiner, M., and Shmerling, D. H. (1970). The pathogenesis of coeliac disease. (Abstr.) Gut, 11, 1058-1059.

Sprinz, H., Sribhibhadh, E. J., Gangarosa, E. J., Benyajata, C, Kundel, D., and Halstead, S. (1962). Biopsy of small bowel of Thai people. Amer. J. clin. Path., 38, 43-51.

Stewart, J. S., Pollock, D. J., Hoffbrand, A. V., Mollin, D. L., and Booth, C. C. (1967). A study of proximal and distal intestinal structure and absorptive function in idiopathic steatorrhoea. Quart. J. Med., 36, 425-444.
Swanson, V. L., and Thomassen, R. W. (1965). Pathology of the jejunal mucosa in tropical sprue. Amer. J. Path., 46, 511-551.

Swanson, V. L., Wheby, M. S., and Bayless, T. M. (1966). Morphologic effects of folic acid and vitamin $\mathbf{B}_{12}$ on the jejunal lesion 으 of tropical sprue. Amer. J. Path., 49, 167-191.

Thurlbeck, W. M., Benson, J. A., and Dudley, H. R. (1960). The histopathologic changes of sprue and their significance. Amer. J. clin. Path., 34, 108-117.

Tofler, A. H., Hukill, P. B., and Spiro, H. M. (1963). Brown bowel syndrome. Ann. intern. Med., 58, 872-877.

Townley, R. R. W., Cass, M. H., and Anderson, C. M. (1964). Small $\overline{\bar{\sigma}}$ intestinal mucosal patterns of coeliac disease and idiopathic $\vec{D}$ steatorrhoea seen in other situations. Gut, 5, 51-55.

Trier, J. S. (1962). Morphologic alterations induced by methotrexale in the mucosa of the human proximal intestine. Gastroenterology, 42, 295-305.

Waldmann, T. A. (1970). Modern Trends in Gastroenterology, vol. 4. p. 136, edited by W. I. Card and B. Creamer. Butterworth, London.

Waldmann, T. A., Wochner, R. D., Laster, L., and Gordon, R. S S (1967). Allergic gastroenteropathy. New Engl. J. Med., 276, 긍 761-769.

Wall, A. J., Douglas, A. J., Booth, C. C., and Pearse, A. G. E. (1970). Response of the jejunal mucosa in adult coeliac disease to oral í prednisolone. Gut, 11, 7-14.

Watson, J. H. L., and Haubrich, W. S. (1969). Bacilli bodies in the lumen and epithelium of the jejunum in Whipple's disease. $\vec{\odot}$
Lab. Invest., 21, 347-357.

Whalen, G. E., Rosenberg, E. B., Strickland, G. T., Gutman, R. A., Cross, J. H., Watten, R. H., Uylangeo, C., and Dizou, J. J (1969). Intestinal capillariasis. A new disease in man. Lancet, 1, 13-16.

Whipple, G. H. (1907). A hitherto undescribed disease characterised anatomically by deposits of fat and fatty acids in the intestinal and mesenteric lymphatic tissues. (Intestinal lipodistrophy.) 을 Johns Hopk. Hosp. Bull., 18, 382-391.

Whitehead, R. (1968a). Primary lymphadenopathy complicating $\rightarrow$ idiopathic steatorrhoea. Gut, 9, 569-575.

Whitehead, R. (1968b). Recent Advances in Clinical Pathology, series $\mathrm{Q},-$ p. 385, edited by S. C. Dyke. Churchill, London.

Wiernik, G. (1966). In vivo cell kinetics of a normal human tiss Brit. med. J., 2, 385-387.

Wiernik, G., Shorter, R. G., and Creamer, B. (1962). The arrest. intestinal epithelial 'turnover' by the use of x-irradiation. Gut 3, 26-31.

Wilson, S., and Thompson, A. E. (1964). A fatal case of strongy-음 loidiasis. J. Path. Bact., 87, 169-176. 